\title{
NOVÉ POZNATKY KU KONŠTRUKCIÁM A TECHNOLÓGIÁM VÝROBY ŠPERKU Z DOBY HALŠTATSKEJ ZO SMOLENÍC-MOLPÍRA ${ }^{1}$
}

\author{
Michal Felcan - Susanne Stegmann-Rajtár - Ján Tirpák
}

DOI: https://doi.org/10.31577/szausav.2019.suppl.1.8

Keywords: Smolenice-Molpír, fortified hilltop settlement, Hallstatt period, North- and Southeastern Hallstatt culture, cultural contacts, jewels, construction and technology of metal producing

\section{New data on constructions and technologies of Hallstatt period jewellery production from Smolenice-Molpír}

The gradual processing of the large find collections of archaeological material from Smolenice-Molpír hillfort brings results to the constructions and technologies of production of some types of metal objects. The aim of this paper is to provide the first preliminary results of analyses of selected types of fibulae as well as circular bracelets made of copper alloys. Analyses are focused on obtaining more precise and relevant knowledge about their composition, working and technological processes in their production and used raw materials. These are types of fibulae and bracelets that have been commonly found in the material culture of the North- and Southeastern Hallstatt culture in the $7^{\text {th }}$ and early $6^{\text {th }}$ centuries BC. All the analyzed metal objects presented in this study come from III. Yard of the hillfort.

\section{ÚVOD}

Z pohladu dejín bádania je osídlenie na vrchu Molpír v Smoleniciach známe už od konca 19. storočia, kedy sa vd’aka N. Sándorfimu objavili v odbornej literatúre prvé informácie o archeologických nálezoch na tejto výšinnej polohe (Sándorfi 1890; 1896). O niekolkko rokov neskôr sa táto významná lokalita objavila v súpise fortifikácii v bývalej bratislavskej župe, kam sa dostala ako jediný „pohanský hrad“ (Könyöki 1905, 19). O podrobné zameranie sa zaslúžil až Š. Janšák, ktorý následne celkový plán výšinného sídliska a jeho opevnenia aj publikoval (Janšák 1929; 1930, obr. 38). Na výsledky jeho práce od r. 1963 naviazali terénne výskumy M. Dušeka (od roku 1967 spolu so S. Dušekovou), ktoré boli ukončené v r. 1971 (Dušek/ Dušek 1984; 1995). Výskumy menšieho rozsahu sa realizovali v rokoch 2008 (Ludwig/Stegmann-Rajtár/ Tirpák 2010) a 2015 (Felcan/Pašteka/Stegmann-Rajtár, v tlači).

Už počas výskumov v rokoch 1963-1971 sa zistilo, že ide o nálezisko s viacnásobným osídlením v mnohých obdobiach praveku až včasnej doby historickej. Celý areál hradiska s vel'kostou približne 15,2 ha sa člení na tri časti, na I. a II. nádvorie, kde sa skúmali iba menšie plochy a na najvyššie položené III. nádvorie, tzv. akropolu, ktorá sa skúmala najintenzívnejšie. Autorom výskumu sa podarilo zdokumentovat a publikovat' $\mathrm{v}$ dvoch dieloch katalógu prevažnú čast' keramiky, ako aj drobných nálezov z hliny, bronzu, železa, kostí, parohoviny, kameňa, ale aj z jantáru, skla a iných materiálov (Dušek/Dušek 1984; 1995, 71). ${ }^{2}$ Najväčšia koncentrácia nálezov z doby halštatskej bola zistená na III. nádvorí, kde sa v rade vedla seba odkryli obydlia pozdíž opevnenia v severnej a východnej časti, ako aj v obydliach $v$ jeho centrálnej časti. Početné nálezy sa d’alej nachádzali aj v stavbe s údajným kultovým významom, v priestore pecí, cisterny, ako aj dvoch vstupných brán (Müller 2012; 2017; Stegmann-Rajtár 1998, obr. 2; 2005). V odkrytých stavbách obytného ako aj hospodárskeho charakteru je doložená rozmanitá remeselná a hospodárska

\footnotetext{
1 Príspevok vznikol v rámci projektu grantovej agentúry VEGA „Metalurgia a využitie farebných kovov v mladšom praveku až vo včasnom stredoveku na Slovensku“ (02/0115/18).

2 V oboch katalógoch sú publikované aj nálezy, ktoré patria do neolitu/eneolitu, staršej a strednej doby bronzovej, doby popolnicových polí, strednej až neskorej doby laténskej, doby rímskej, doby stahovania národov a do doby včasného až vrcholného stredoveku.
} 
činnost' (Müller 2012, obr. 243), ku ktorej patrila tiež výroba keramiky a kovových predmetov. Zo Smoleníc-Molpíra pochádza široký sortiment kovových výrobkov aj z bronzu a železa, najmä rôznych nástrojov, náradia, konského postroja a jeho súčastí, ako aj šperkov a súčastí odevu (Stegmann-Rajtár 2005). V tejto štúdii sa budeme venovat iba jednej špeciálnej skupine nálezov, a to sponám a náramkom. Lod'kovité spony typu Šmarjeta mali tažisko výskytu v juhovýchodohalštatskej kultúre, odkial' sa rozšírili aj do severovýchodohalštatskej kultúry (obr. 6; Stegmann-Rajtár 2009, 82, obr. 14). Typologické zastúpenie lod'kovitých spôn je vel'mi variabilné (hladké, s priečnym rebrom atd'). Druhú, tiež pomerne početnú skupinu sledovaných predmetov tvoria masívne typy náramkov zdobené rebrovaním.

Podla pomerne jednotnej stavebnej koncepcie a na základe datovania vedúcich typov predmetov z akropoly možno predpokladat,' že obydlia vznikli a boli obývané zrejme v rovnakom časovom období, ktorého vrcholné obdobie osídlenia spadá do 7. a na začiatok 6. stor. pred n. 1. (Barta a i. 2017; Müller 2012; Parzinger/Stegmann-Rajtár 1988; Stegmann-Rajtár 1992; 2017, tab. 1).

Opevnené výšinné sídlisko Smolenice-Molpír, okr. Trnava, bolo vybudované na východnom svahu Malých Karpát, na strategicky výhodnom mieste nedaleko Jablonického priesmyku, ktorý spájal oblasti Považia s Pomoravím. V dobe halštatskej týmto miestom prechádzala obchodná dial'ková komunikácia, ktorá smerovala z juhovýchodoalpskej oblasti, cez Bratislavskú bránu a pokračovala d’alej na severovýchod do severozápadnej časti Karpát. Molpír bol vybudovaný v kontaktnej zóne východohalštatského a lužického kultúrneho okruhu, ako aj jazdecko-nomádskeho kultúrneho spoločenstva východokarpatskej oblasti a mal klúčové postavenie $\mathrm{v}$ priestore rozšírenia východohalštatskej kultúry (Hellmuth 2006; Müller 2012; Stegmann-Rajtár 1998; 2002a; 2005; 2017). Nálezový materiál z Molpíra je preto vel’mi bohatý, rôznorodý a poukazuje na jeho regionálne, ako aj nadregionálne kontakty. Okrem množstva nálezov keramického riadu a výrobkov z hliny sa tu našlo aj vel'ké množstvo drobných predmetov, ktoré reprezentujú každodenný život obyvatelov na tomto hradisku. Medzi unikátne nálezy patria napr. fragmenty bronzových prílb (tzv. miskovitý typ) alebo bronzových spôn lod’kovitého typu, ku ktorým nachádzame jednoznačné paralely v centrálnych opevnených sídliskách a pohrebiskách juhovýchodoalpskej oblasti, najmä v Štajersku, Slovinsku a Zadunajsku. Čast’ z nich bola s vel'kou pravdepodobnostou importom, ale u niektorých predpokladáme, že sa mohli vyrábat’ aj priamo na Molpíri (Novotná 2001; StegmannRajtár 1998; 2001; 2002b; 2009, 82, obr. 14). Molpír tak zjavne sprostredkoval priame kontakty aj medzi kultúrnym prostredím stredného a severovýchodného Zadunajska s juhomoravskou oblastou (Parzinger/ Nekvasil/Barth 1995; Patek 1993; Stegmann-Rajtár 1992; 2005; Teržan 1990). Typologicky najrozmanitejšia bola produkcia keramických nádob a tiež rôznych predmetov z hliny, napr. praslenov a tkáčskych závaží, ktoré sa zachovali skoro v každom z odkrytých obydlí (Belanová 2002; Müller 2012; Stegmann-Rajtár 1998; 2001; 2005).

\section{METÓDA DOKUMENTÁCIE}

V rámci sledovania trasológie, konštrukcií a výrobných postupov vybraných typov šperkov bolo nutné si na začiatok stanovit optimálne podmienky zberu dát. Technická kresba už tradične používaná pre dokumentáciu artefaktov $\mathrm{v}$ archeológií sa pre naše potreby javila ako nepoužitel'ná. Dobre to ilustruje príklad rebrovaného náramku (obr. 4: D) v originálnej publikácii Dušekovcov (Dušek/Dušek 1995, tab. 86: 4) a reálna podoba toho istého náramku na našich fotografiách (obr. 4: A-C). Podobne je to aj s kresbami ostatných skúmaných predmetov (Dušek/Dušek 1984; 1995; Novotná 2001), ktoré sú postačujúce na základnú typologicko-chronologickú analýzu, avšak pre detailnejší výskum jednotlivých remeselných činností a pracovných postupov už nestačia.

Niektoré vybrané predmety sme začali dokumentovat pod digitálnym mikroskopom s komerčným označením Keyence VHX1000. Neskôr sme kvôli časovej a finančnej náročnosti prešli na rýchlejšiu, flexibilnejšiu a cenovo dostupnejšiu metódu snímkovania s využitím digitálnej zrkadlovky Canon EOS 70D s makro objektívom, s ohniskovou vzdialenostou $60 \mathrm{~mm}$ ovládanou na statíve zo vzdialenosti pomocou softvéru EOS Utility. Samotné snímkovanie poskytlo efektívnejšie a lacnejšie riešenie ako digitálny mikroskop, pričom kvalitatívne a pre potreby práce spĺňa všetky podstatné detaily snímkovania. Vybrané dokumentované predmety sú zobrazené na obrázkoch 1-4 a predstavujú reprezentatívnu vzorku šperkov z Molpíra, na ktorých chceme poukázat’ všetky podstatné trasologické stopy, konštrukcie a technologické výrobné postupy. Dôležité detaily boli zväčšené a sú prezentované v rámčekoch jednotlivých obrázkov. Na niektorých z nich bude možné preukázał priamu kovolejársku a kovotepec- 
kú aktivitu komunít žijúcich na Molpíri a ich priestorové situovanie v staršej dobe železnej v rámci III. nádvoria hradiska.

\section{RFA METÓDA}

Metóda röntgenofluorescenčnej analýzy (d’alej len RFA analýzy) chemického zloženia prvkov týchto predmetov otvára diskusiu $\mathrm{v}$ mnohých smeroch. Jedným z nich je aj terminologická otázka medených zliatín a bronzu samotného.

RFA analýza (ED-XRF) je metóda nedeštruktívneho zistovania chemického zloženia predmetov. Je založená na meraní charakteristického röntgenového žiarenia vzbudeného ožarovaním skúmaného predmetu. Je rýchla, presná, opakovatelná a nedeštruktívna, nevyžaduje si úpravu vzoriek, analyzovaný predmet nepoškodzuje. ED-XRF je analytická metóda určenia chemického zloženia a je vhodná hlavne pre analýzu makroprvkov, prípadne aj niektorých stopových prvkov. Röntgenová fluorescenčná spektrometria je relatívna analytická metóda, pretože meraná veličina sa musí vztảahovat̉ na zloženie vzorky pomocou výpočtov alebo porovnaním so štandardmi. Vlastné meranie je realizované väčšinou z povrchu skúmaného predmetu, pri ktorom sa spektrometrom zistujú hodnoty koncentrácie (Wt\% hmotnostné percentá) jednotlivých prvkov. Analýzy predmetov boli realizované ručným röntgen-fluorescenčným spektrometrom DELTA CLASSIC+ od firmy Olympus z USA, ktorý je určený pre nedeštruktívne kvantitatívne analýzy archeologických predmetov, drahých kovov a zliatin drahých kovov. Analyzátor bez zanechania stôp stanovil percentuálny obsah viacerých prvkov, z ktorých zobrazujeme 11 podstatných (Cu, Sn, $\mathrm{Pb}, \mathrm{Zn}, \mathrm{Ga}, \mathrm{As}, \mathrm{Ag}, \mathrm{Sb}, \mathrm{Fe}, \mathrm{Ni}$, Bi; tabela 1).

Tabela 1. Smolenice, poloha hradisko Molpír (okr. Trnava). Výsledky RFA analýzy spôn a náramkov z doby halštatskej. Merania J. Tirpák.

\begin{tabular}{|c|c|c|c|c|c|c|c|c|c|c|c|c|c|c|}
\hline Meraný predmet & Por.č. & Prír.č. & $\mathrm{Cu}$ & Sn & $\mathrm{Pb}$ & $\mathrm{Zn}$ & $\mathrm{Ga}$ & As & $\mathrm{Ag}$ & $\mathrm{Sb}$ & $\mathrm{Fe}$ & $\mathrm{Ni}$ & $\mathrm{Bi}$ & $\begin{array}{c}\text { hmotnost' } \\
(\mathrm{g})\end{array}$ \\
\hline $\begin{array}{l}\text { lod'. spona s postrannými } \\
\text { výčnelkami }\end{array}$ & 1 & 7051 & 65,38 & 30,07 & 2,50 & 0,77 & 0,00 & 0,73 & 0,55 & 0,00 & 0,00 & 0,00 & 0,00 & 7,42 \\
\hline $\begin{array}{l}\text { lúčovitá železná spona } \\
\text { s nitom }\end{array}$ & 2 & 7219 & 0,59 & 0,00 & 0,00 & 0,00 & 0,00 & 0,28 & 0,00 & 0,00 & 99,13 & 0,00 & 0,00 & \\
\hline $\begin{array}{l}\text { nezdobená lod'. spona } \\
\text { s nitom }\end{array}$ & 3 & 7290 & 47,81 & 37,06 & 6,27 & 0,84 & 0,00 & 2,04 & 0,97 & 0,00 & 4,40 & 0,61 & 0,00 & 6,91 \\
\hline $\begin{array}{l}\text { lod'. spona typu Šmarjeta } \\
\text { s nitom }\end{array}$ & 4 & 7467 & 53,92 & 26,70 & 4,77 & 0,83 & 0,00 & 2,88 & 1,93 & 3,05 & 5,44 & 0,48 & 0,00 & 2,14 \\
\hline nezdobená lod'. spona & 5 & 7502 & 71,32 & 18,63 & 4,82 & 0,94 & 0,00 & 1,83 & 0,75 & 1,18 & 0,00 & 0,53 & 0,00 & 13,89 \\
\hline $\begin{array}{l}\text { zachycovač halštatskej } \\
\text { spony }\end{array}$ & 6 & 7512 & 53,48 & 32,69 & 3,94 & 0,65 & 0,00 & 4,01 & 1,78 & 2,51 & 0,00 & 0,94 & 0,00 & 0,71 \\
\hline $\begin{array}{l}\text { lod'. spona typu Šmarjeta } \\
\text { s nitom }\end{array}$ & 7 & 7536 & 39,56 & 51,22 & 4,22 & 0,00 & 0,00 & 1,95 & 1,06 & 0,00 & 1,36 & 0,62 & 0,00 & 3,59 \\
\hline hadovitá spona & 8 & 7709 & 41,59 & 55,05 & 1,89 & 0,00 & 0,00 & 1,47 & 0,00 & 0,00 & 0,00 & 0,00 & 0,00 & 4,44 \\
\hline lod'. spona typu Šmarjeta & 9 & 7720 & 76,48 & 17,80 & 1,73 & 0,88 & 0,00 & 0,96 & 0,50 & 0,88 & 0,55 & 0,23 & 0,00 & 4,87 \\
\hline $\begin{array}{l}\text { ihla halštatskej spony } \\
\text { s nitom }\end{array}$ & 10 & 7721 & 74,30 & 18,04 & 3,64 & 0,66 & 0,00 & 1,23 & 0,53 & 1,26 & 0,34 & 0,00 & 0,00 & 1,85 \\
\hline ihla halštatskej spony & 11 & 7759 & 89,27 & 9,28 & 1,45 & 0,00 & 0,00 & 0,00 & 0,00 & 0,00 & 0,00 & 0,00 & 0,00 & 1,34 \\
\hline $\begin{array}{l}\text { lod'. spona typu Šmarjeta } \\
\text { s nitom }\end{array}$ & 12 & 7899 & 62,11 & 34,41 & 0,86 & 0,75 & 0,00 & 1,10 & 0,41 & 0,00 & 0,00 & 0,36 & 0,00 & 4,1 \\
\hline lod'. spona typu Šmarjeta & 13 & 7903 & 85,23 & 6,65 & 2,62 & 0,94 & 0,00 & 1,55 & 0,83 & 1,18 & 0,64 & 0,36 & 0,00 & 2,1 \\
\hline $\begin{array}{l}\text { zachycovač halštatskej } \\
\text { spony s nitom }\end{array}$ & 14 & 8026 & 60,09 & 29,36 & 4,03 & 2,50 & 0,00 & 3,03 & 0,64 & 0,00 & 0,00 & 0,34 & 0,00 & 2,26 \\
\hline $\begin{array}{l}\text { lod'. spona typu Šmarjeta } \\
\text { s nitom }\end{array}$ & 15 & 8099 & 40,77 & 43,53 & 4,87 & 0,95 & 0,00 & 2,39 & 1,27 & 2,78 & 2,95 & 0,48 & 0,00 & 5,88 \\
\hline $\begin{array}{l}\text { lod'. spona s mrežovanými } \\
\text { priečnymi pásmi }\end{array}$ & 16 & 8127 & 77,56 & 16,68 & 0,38 & 1,09 & 0,00 & 1,05 & 0,96 & 1,57 & 0,34 & 0,38 & 0,00 & 3,34 \\
\hline ihla halštatskej spony & 17 & 8573 & 84,66 & 10,97 & 0,52 & 0,98 & 0,00 & 0,59 & 0,52 & 0,91 & 0,53 & 0,32 & 0,00 & 0,86 \\
\hline $\begin{array}{l}\text { zachycovač halštatskej } \\
\text { spony }\end{array}$ & 18 & 8710 & 67,77 & 26,90 & 2,41 & 0,00 & 0,00 & 0,51 & 0,91 & 0,00 & 1,16 & 0,34 & 0,00 & \\
\hline $\begin{array}{l}\text { lúčovitá spona s } \\
\Delta \text { prierezom s nitom }\end{array}$ & 19 & 8729 & 56,76 & 28,98 & 8,97 & 0,87 & 1,07 & 1,92 & 0,94 & 0,00 & 0,00 & 0,49 & 0,00 & 6,54 \\
\hline $\begin{array}{l}\text { lod'. spona typu Šmarjeta } \\
\text { s nitom }\end{array}$ & 20 & 8878 & 80,51 & 17,90 & 0,67 & 0,67 & 0,00 & 0,24 & 0,00 & 0,00 & 0,00 & 0,00 & 0,00 & 13,86 \\
\hline
\end{tabular}


Tabela 1. Pokračovanie.

\begin{tabular}{|c|c|c|c|c|c|c|c|c|c|c|c|c|c|c|}
\hline Meraný predmet & Por.č. & Prír.č. & $\mathrm{Cu}$ & Sn & $\mathrm{Pb}$ & $\mathrm{Zn}$ & $\mathrm{Ga}$ & As & $\mathrm{Ag}$ & $\mathrm{Sb}$ & $\mathrm{Fe}$ & $\mathrm{Ni}$ & $\mathrm{Bi}$ & $\begin{array}{c}\text { hmotnost' } \\
\text { (g) }\end{array}$ \\
\hline $\begin{array}{l}\text { Iod'. spona typu Šmarjeta s } \\
\text { dvojnásobným nitom }\end{array}$ & 21 & 8879 & 82,46 & 13,37 & 1,55 & 0,53 & 0,00 & 0,00 & 0,66 & 1,20 & 0,00 & 0,24 & 0,00 & 5,08 \\
\hline $\begin{array}{l}\text { lod'. spona typu Šmarjeta } \\
\text { s nitom }\end{array}$ & 22 & 8880 & 82,58 & 14,05 & 1,42 & 0,63 & 0,00 & 0,00 & 0,44 & 0,88 & 0,00 & 0,00 & 0,00 & 8,14 \\
\hline $\begin{array}{l}\text { zachycovač halštatskej } \\
\text { spony }\end{array}$ & 23 & 8884 & 77,78 & 19,72 & 0,79 & 0,84 & 0,00 & 0,41 & 0,00 & 0,00 & 0,31 & 0,15 & 0,00 & 1,22 \\
\hline $\begin{array}{l}\text { zachycovač halštatskej } \\
\text { spony }\end{array}$ & 24 & 8885 & 73,22 & 18,97 & 2,74 & 0,61 & 0,00 & 1,06 & 0,84 & 1,78 & 0,34 & 0,45 & 0,00 & 0,48 \\
\hline $\begin{array}{l}\text { lod'. spona s mrež. } \\
\text { priečnymi pásmi s nitom }\end{array}$ & 25 & 9074 & 59,10 & 33,17 & 1,81 & 0,67 & 0,00 & 1,16 & 0,38 & 0,00 & 0,00 & 3,71 & 0,00 & \\
\hline meranie, zachycovač & 25 & 9074 & 60,77 & 31,33 & 1,67 & 0,70 & 0,00 & 1,11 & 0,33 & 0,00 & 0,00 & 4,09 & 0,00 & \\
\hline meranie, ihla & 25 & 9074 & 46,32 & 50,59 & 0,83 & 0,00 & 0,00 & 1,38 & 0,00 & 0,00 & 0,00 & 0,88 & 0,00 & \\
\hline meranie, nit & 25 & 9074 & 58,73 & 36,26 & 1,89 & 0,00 & 0,00 & 1,69 & 0,00 & 0,00 & 0,00 & 1,43 & 0,00 & \\
\hline $\begin{array}{l}\text { zachycovač halštatskej } \\
\text { spony }\end{array}$ & 26 & 9075 & 50,79 & 40,51 & 2,36 & 0,00 & 0,00 & 1,40 & 0,45 & 0,00 & 0,00 & 4,49 & 0,00 & 0,62 \\
\hline $\begin{array}{l}\text { lod'. spona typu Šmarjeta } \\
\text { s nitom }\end{array}$ & 27 & 9138 & 83,98 & 14,20 & 0,58 & 0,59 & 0,00 & 0,30 & 0,00 & 0,00 & 0,35 & 0,00 & 0,00 & 5,32 \\
\hline $\begin{array}{l}\text { nedokončená lúčovitá } \\
\text { spona }\end{array}$ & 28 & 9235 & 80,60 & 14,00 & 0,78 & 1,14 & 0,00 & 1,39 & 0,47 & 0,00 & 1,17 & 0,44 & 0,00 & 3,63 \\
\hline lod'. spona typu Šmarjeta & 29 & 9259 & 76,66 & 19,37 & 1,61 & 0,56 & 0,00 & 0,00 & 0,47 & 0,92 & 0,00 & 0,41 & 0,00 & 6,37 \\
\hline $\begin{array}{l}\text { zachycovač halštatskej } \\
\text { spony }\end{array}$ & 30 & 9281 & 52,63 & 42,76 & 2,51 & 0,00 & 0,00 & 0,00 & 0,00 & 0,00 & 2,10 & 0,00 & 0,00 & 0,92 \\
\hline lúčovitá železná spona & 31 & 9332 & 0,00 & 0,00 & 0,00 & 0,00 & 0,00 & 0,23 & 0,00 & 0,00 & 99,77 & 0,00 & 0,00 & 1,83 \\
\hline lod'. spona typu Šmarjeta & 32 & 9540 & 71,11 & 23,62 & 1,22 & 1,08 & 0,00 & 0,89 & 0,49 & 1,00 & 0,37 & 0,22 & 0,00 & 4,92 \\
\hline $\begin{array}{l}\text { lod'. spona s mrežovanými } \\
\text { priečnymi pásmi }\end{array}$ & 33 & 9744 & 76,93 & 16,65 & 2,58 & 0,59 & 0,00 & 1,20 & 0,50 & 1,07 & 0,00 & 0,21 & 0,27 & \\
\hline meranie, zachycovač & 33 & 9744 & 74,87 & 18,50 & 2,63 & 0,53 & 0,00 & 1,00 & 0,63 & 1,39 & 0,00 & 0,18 & 0,27 & \\
\hline meranie, ihla 1 & 33 & 9744 & 74,31 & 19,52 & 3,32 & 0,55 & 0,00 & 0,00 & 0,66 & 1,23 & 0,00 & 0,17 & 0,23 & \\
\hline meranie, ihla 2 & 33 & 9744 & 78,47 & 16,44 & 1,84 & 0,57 & 0,00 & 0,80 & 0,55 & 1,07 & 0,00 & 0,26 & 0,00 & 1,64 \\
\hline $\begin{array}{l}\text { lod'. spona typu Šmarjeta } \\
\text { s nitom }\end{array}$ & 34 & 9827 & 68,91 & 26,55 & 0,77 & 1,37 & 0,00 & 1,06 & 0,69 & 0,00 & 0,00 & 0,65 & 0,00 & 4,47 \\
\hline $\begin{array}{l}\text { lod'. spona s mrežovanými } \\
\text { priečnymi pásmi }\end{array}$ & 35 & 9905 & 83,07 & 13,18 & 1,04 & 0,67 & 0,00 & 0,70 & 0,32 & 1,02 & 0,00 & 0,00 & 0,00 & 5,82 \\
\hline $\begin{array}{l}\text { zachycovač halštatskej } \\
\text { spony }\end{array}$ & 36 & 9906 & 68,50 & 22,57 & 2,61 & 0,66 & 0,00 & 1,99 & 1,09 & 1,67 & 0,00 & 0,91 & 0,00 & 1,72 \\
\hline $\begin{array}{l}\text { lod'. spona s mrež. } \\
\text { priečnymi pásmi s nitom }\end{array}$ & 37 & 9943 & 74,86 & 17,50 & 1,70 & 0,72 & 0,00 & 1,74 & 0,87 & 1,40 & 0,49 & 0,72 & 0,00 & 2,31 \\
\hline $\begin{array}{l}\text { lod'. spona s ryhovanou } \\
\text { výzdobou }\end{array}$ & 38 & 9982 & 84,91 & 10,35 & 3,32 & 0,61 & 0,00 & 0,00 & 0,00 & 0,00 & 0,58 & 0,23 & 0,00 & 8,46 \\
\hline $\begin{array}{l}\text { zachycovač halštatskej } \\
\text { spony }\end{array}$ & 39 & 10089 & 42,61 & 36,07 & 4,81 & 0,00 & 0,00 & 5,38 & 4,80 & 3,70 & 0,00 & 2,63 & 0,00 & 0,93 \\
\hline lúčovitá spona s nitom & 40 & 10100 & 84,50 & 12,24 & 1,60 & 0,60 & 0,00 & 0,00 & 0,00 & 0,00 & 0,89 & 0,16 & 0,00 & \\
\hline meranie, zachycovač & 40 & 10100 & 82,85 & 15,27 & 1,21 & 0,48 & 0,00 & 0,00 & 0,00 & 0,00 & 0,00 & 0,19 & 0,00 & \\
\hline meranie, ihla & 40 & 10100 & 89,93 & 8,37 & 0,27 & 1,18 & 0,00 & 0,00 & 0,00 & 0,00 & 0,25 & 0,00 & 0,00 & \\
\hline $\begin{array}{l}\text { lod'. spona s mrež. prieč. } \\
\text { pásmi s dvojnás. nitom }\end{array}$ & 41 & 10333 & 61,65 & 31,36 & 2,82 & 0,64 & 0,00 & 1,38 & 0,57 & 0,00 & 0,00 & 1,57 & 0,00 & 3,54 \\
\hline $\begin{array}{l}\text { lod'. spona s mrež. } \\
\text { priečnymi pásmi s nitom }\end{array}$ & 42 & 10334 & 61,87 & 30,24 & 4,73 & 0,77 & 0,00 & 1,84 & 0,55 & 0,00 & 0,00 & 0,00 & 0,00 & 4,71 \\
\hline $\begin{array}{l}\text { zachycovač halštatskej } \\
\text { spony }\end{array}$ & 43 & 10335 & 71,23 & 24,80 & 2,01 & 0,50 & 0,00 & 0,00 & 0,42 & 0,00 & 0,00 & 1,04 & 0,00 & 0,41 \\
\hline $\begin{array}{l}\text { zachycovač halštatskej } \\
\text { spony }\end{array}$ & 44 & 10337 & 64,99 & 29,95 & 2,35 & 0,52 & 0,00 & 0,60 & 0,42 & 0,00 & 0,00 & 1,17 & 0,00 & 0,27 \\
\hline $\begin{array}{l}\text { lod'. spona s mrež. } \\
\text { priečnymi pásmi s nitom }\end{array}$ & 45 & 10418 & 86,60 & 4,69 & 4,42 & 0,70 & 0,00 & 0,80 & 0,40 & 1,02 & 1,10 & 0,27 & 0,00 & 21,44 \\
\hline $\begin{array}{l}\text { zachycovač halštatskej } \\
\text { spony }\end{array}$ & 46 & 10769 & 66,95 & 24,91 & 4,71 & 0,00 & 0,00 & 2,47 & 0,96 & 0,00 & 0,00 & 0,00 & 0,00 & 0,69 \\
\hline $\begin{array}{l}\text { lod'. spona s mrež. } \\
\text { priečnymi pásmi s nitom }\end{array}$ & 47 & 10882 & 50,97 & 44,52 & 0,39 & 0,69 & 0,00 & 1,74 & 1,01 & 0,00 & 0,00 & 0,68 & 0,00 & 2,98 \\
\hline meranie, ihla & 47 & 10882 & 72,57 & 18,47 & 2,27 & 0,73 & 0,00 & 2,25 & 1,15 & 1,60 & 0,00 & 0,96 & 0,00 & \\
\hline lod'. spona typu Šmarjeta & 48 & 10961 & 36,91 & 55,60 & 0,67 & 0,68 & 0,00 & 1,60 & 1,08 & 0,00 & 1,98 & 1,48 & 0,00 & 1,4 \\
\hline $\begin{array}{l}\text { lučovitá spona s rytými } \\
\text { líniami }\end{array}$ & 49 & 11003 & 66,77 & 22,34 & 2,45 & 0,67 & 0,00 & 2,87 & 1,18 & 3,21 & 0,00 & 0,51 & 0,00 & 3,7 \\
\hline $\begin{array}{l}\text { lod'. spona typu Šmarjeta } \\
\text { s nitom }\end{array}$ & 50 & 11047 & 52,08 & 42,67 & 1,39 & 0,96 & 0,00 & 1,43 & 0,74 & 0,00 & 0,00 & 0,73 & 0,00 & 5,54 \\
\hline
\end{tabular}


Tabela 1. Pokračovanie.

\begin{tabular}{|c|c|c|c|c|c|c|c|c|c|c|c|c|c|c|}
\hline Meraný predmet & Por.č. & Prír.č. & $\mathrm{Cu}$ & Sn & $\mathrm{Pb}$ & $\mathrm{Zn}$ & $\mathrm{Ga}$ & As & $\mathrm{Ag}$ & $\mathrm{Sb}$ & $\mathrm{Fe}$ & $\mathrm{Ni}$ & $\mathrm{Bi}$ & $\begin{array}{l}\text { hmotnost' } \\
\text { (g) }\end{array}$ \\
\hline fragmenty lod'kovitej spony & 51 & 11117 & 71,90 & 21,42 & 0,47 & 0,69 & 0,00 & 1,83 & 1,10 & 2,03 & 0,00 & 0,56 & 0,00 & 0,76 \\
\hline $\begin{array}{l}\text { zachycovač nedokončenej } \\
\text { halštatskej spony }\end{array}$ & 52 & 11140 & 39,58 & 44,74 & 4,68 & 0,00 & 0,00 & 2,01 & 2,25 & 3,40 & 3,34 & 0,00 & 0,00 & 1,86 \\
\hline $\begin{array}{l}\text { lúčovitá cínová spona } \\
\text { s priečnymi líniami }\end{array}$ & 53 & 11147 & 17,75 & 74,10 & 0,21 & 0,00 & 0,00 & 1,80 & 2,01 & 3,60 & 0,00 & 0,53 & 0,00 & 0,83 \\
\hline $\begin{array}{l}\text { zachycovač halštatskej } \\
\text { spony }\end{array}$ & 54 & 11189 & 81,95 & 14,68 & 0,32 & 0,78 & 0,00 & 0,77 & 0,00 & 0,00 & 0,47 & 1,03 & 0,00 & 1,37 \\
\hline $\begin{array}{l}\text { zachycovač halštatskej } \\
\text { spony }\end{array}$ & 55 & 11190 & 66,23 & 29,67 & 0,22 & 0,00 & 0,00 & 2,84 & 1,04 & 0,00 & 0,00 & 0,00 & 0,00 & 0,46 \\
\hline $\begin{array}{l}\text { zachycovač halštatskej } \\
\text { spony }\end{array}$ & 56 & 11191 & 53,16 & 40,67 & 1,02 & 0,00 & 0,00 & 3,88 & 1,27 & 0,00 & 0,00 & 0,00 & 0,00 & 0,35 \\
\hline ihla halštatskej spony & 57 & 11192 & 76,95 & 13,70 & 2,46 & 0,69 & 0,00 & 1,90 & 1,37 & 1,76 & 0,81 & 0,36 & 0,00 & 0,54 \\
\hline inla halštatskej spony & 58 & 11300 & 87,88 & 10,02 & 0,19 & 0,86 & 0,00 & 0,43 & 0,00 & 0,00 & 0,28 & 0,34 & 0,00 & 0,69 \\
\hline $\begin{array}{l}\text { lod'. spona typu Šmarjeta } \\
\text { s dvonásobným nitom }\end{array}$ & 59 & 11353 & 53,39 & 39,48 & 1,73 & 0,00 & 0,00 & 0,72 & 0,55 & 0,00 & 3,82 & 0,31 & 0,00 & 6,55 \\
\hline lod'. spona typu Šmarjeta & 60 & 11354 & 39,93 & 52,21 & 3,53 & 0,00 & 0,00 & 1,89 & 0,50 & 0,00 & 1,28 & 0,66 & 0,00 & 5,81 \\
\hline $\begin{array}{l}\text { lod'. spona typu Šmarjeta } \\
\text { s nitom na zachycovači }\end{array}$ & 61 & 11444 & 84,76 & 10,70 & 0,87 & 0,67 & 0,00 & 0,79 & 0,76 & 1,13 & 0,00 & 0,31 & 0,00 & 5,61 \\
\hline meranie, zachycovač & 61 & 11444 & 86,35 & 10,08 & 0,97 & 0,00 & 0,00 & 0,00 & 0,95 & 1,41 & 0,00 & 0,24 & 0,00 & \\
\hline $\begin{array}{l}\text { halštatský náramok } \\
\text { s rebrovaním }\end{array}$ & 85 & 10099 & 83,39 & 11,20 & 1,40 & 0,67 & 0,00 & 1,07 & 0,65 & 1,09 & 0,00 & 0,53 & 0,00 & \\
\hline $\begin{array}{l}\text { halštatský náramok } \\
\text { s rebrovaním }\end{array}$ & 86 & 10288 & 60,98 & 17,98 & 14,68 & 1,08 & 0,00 & 1,29 & 0,89 & 2,48 & 0,00 & 0,62 & 0,00 & \\
\hline
\end{tabular}

Technické parametre použitého prístroja sú: DELTA CLASSIC+, energiovo-disperzný RTG-fluorescenčný spektrometer; 4 wattová RTG lampa s prúdom až 200 uA; detektor: Si-PIN; integrovaná full VGA kamera; možnost’ zúženia RTG lúča z 9 na $3 \mathrm{~mm}$ pre analýzu drobných predmetov alebo heterogénnych materiálov. Spektrometer DELTA CLASSIC+, podobne ako aj iné spektrometre, meria iba povrch skúmaného materiálu, a teda nie je zárukou homogenity chemického zloženia meraného materiálu v celom objeme. Poskytuje iba informáciu o zložení povrchovej vrstvy predmetu v danom skúmanom mieste, pričom híbka prieniku röntgenového lúča je daná chemickým zložením materiálu.

RFA metóda sa vyznačuje vel’mi malou penetrabilitou pri meraní zliatin farebných kovov. Odchýlky meraní sú zapríčinené mnohými faktormi. Ide napríklad o heterogenitu kovu a zmeny na povrchu predmetov pôsobením korózie. Konzervačne látky napustené v niektorých objektoch spôsobujú v mnohých prípadoch silný signál prvkov, ktoré nemožno považovat za pôvodné, ako napríklad zinok (Frána a i. 1995, 145-147). Potieranie predmetov širokou škálou konzervačných látok môže okrem zinku rovnako zvýšit hodnoty bária, titánu a olova. Samozrejme v extrémne skorodovaných predmetoch je nutné počítat so zvýšeným obsahom železa, zapríčineným zvyškami pôdy usadených $\mathrm{v}$ póroch skorodovaného predmetu (Bertemes 1989, 138). V súvislosti s prirodzeným korodovaním dochádza aj k lokálnemu zvyšovaniu cínu. Obohatenie arzénom a cínom všeobecne závisí aj od rýchlosti ochladenia objektu po odliatí. V rámci obohatenia cínu môžu vznikat' v niektorých prípadoch vel'mi rozdielne hodnoty na povrchu a v jadre predmetu (Charles 1973, 112, 113, tab. 1; Ottaway 1982; Wouters a i. 1991, 150-153). V niektorých prípadoch však môže byṫ jadro kovových predmetov podstatne homogénnejšie ako povrchové vrstvy kovových predmetov (Frána a i. 1997, 46, tab. 1). Spektrálne analýzy archeologických kovových predmetov sú známe už niekol'ko desatročí. Väčšina odborníkov si dávala za ciel' zistił zloženie zliatin a technológiu ich výroby (Bayley 1988; 1989; Beck a i. 1985; Condamin/Boucher 1973; Craddock 1978; Craddock a i. 2010; Riederer/Briese 1974; Tirpák/Tirpáková/Zábojník 2017; Wobrauschek/Haider/ Streli 1987; a d’alší).

Je samozrejme nevyhnutné priznat' limity RFA metódy, ako aj nízkej početnosti meraní spektrometrom na daný predmet. Prezentovaná štúdia predstavuje preliminárny výsledok RFA analýz, pričom v súčasnosti pracujeme na detailnejších RFA analýzach jednotlivých predmetov a rovnako aj metodicky iných prístupoch analýzy kovových zliatin. Pre komparáciu a porovnanie odchýlky metódy je vhodné použit aj iné metódy ako napríklad neutrónovú aktivačnú analýzu (NAA) pre zistovanie chemického zloženia farebných kovov. Za ideálnych okolností sú analýzy izotopov olova určujúcim nástrojom rozpoznania zdrojov depozít medenej rudy. Rozhodujúca je pravdepodobnost' väzby kovovej zliatiny a t’ažobnej oblasti. Ambície metódy limituje kompozičná homogenita jednotlivých izotopov v zmysle toho, že ju 
možno pripísał využívaniu jediného zdroja, ale aj homogenite sekundárnych zdrojov (Northover 2009, 357-359). Využitie analýz izotopov olova vybraných typov spôn, aj vzhladom na diskutovaný pôvod spôn typu Šmarjeta, by mohlo provenienciu lepšie špecifikovat’ a ozrejmit. Už niektoré publikované výsledky pre neskorú dobu bronzovú a dobu halštatskú v Rakúskych Alpách potvrdili, že medená ruda pochádzala skôr z jedného depozitu, než by predmety vznikli zlievaním starších artefaktov. Príkladom nám sú izotopové analýzy predmetov z pohrebiska Bischofshofen-Pestfriedhof $\mathrm{v}$ Rakúsku (Northover 2009, 362, 363). Výhodou výsledkov merania RFA a d’alších sú absolútne hodnoty, s ktorými je možné narábat využitím kombinačnej štatistiky.

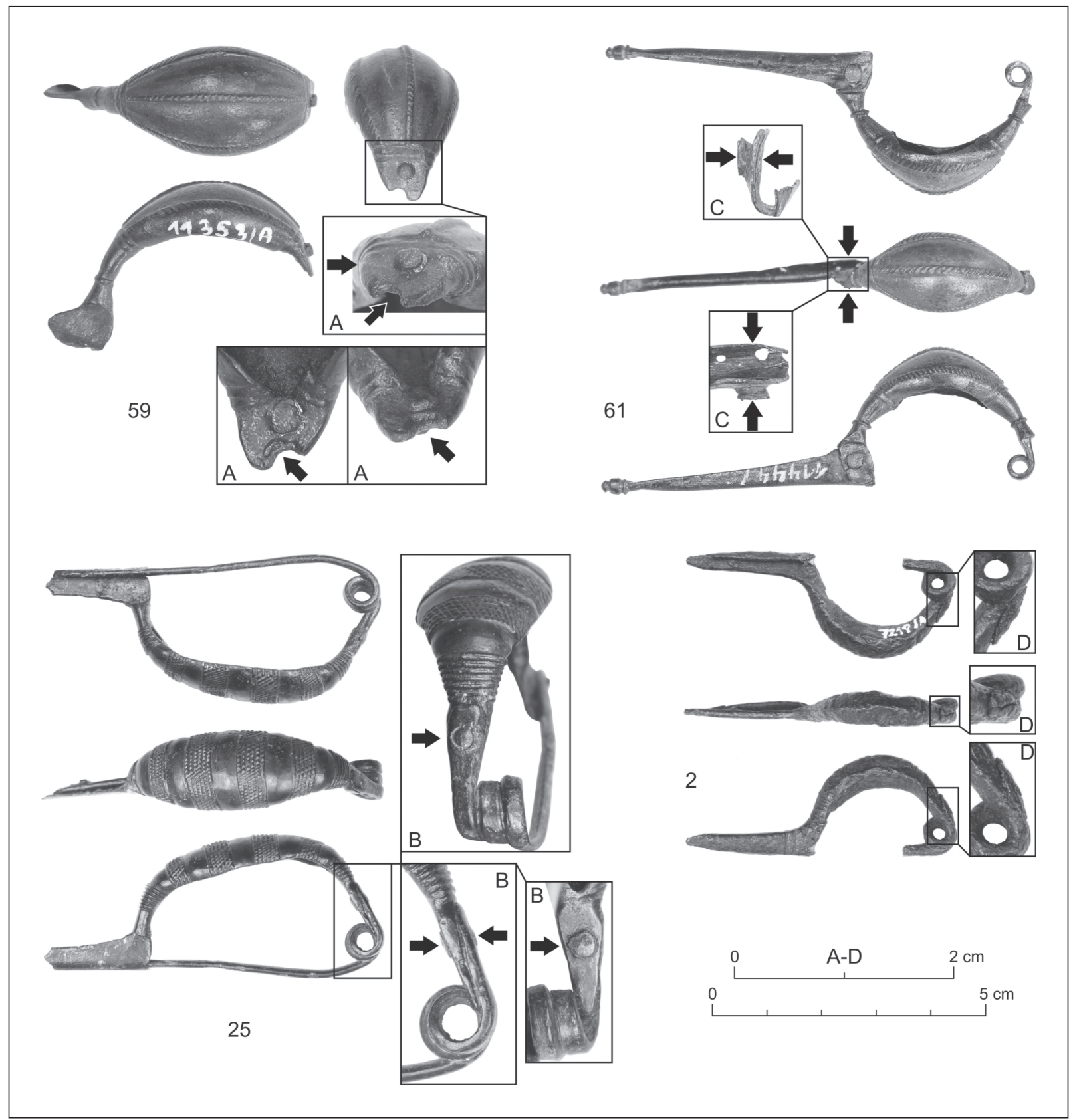

Obr. 1. Smolenice, poloha hradisko Molpír (okr. Trnava). Vybrané nálezy halštatských spôn z III. nádvoria hradiska. Čísla nálezov zodpovedajú číslovaniu v tabele 1. 2 - železo; 25, 59, 61 - zliatiny medi. Grafická mierka ako aj detaily v rámčekoch zodpovedajú vyznačenej grafickej mierke. Fotografie a vizualizácia M. Felcan. 


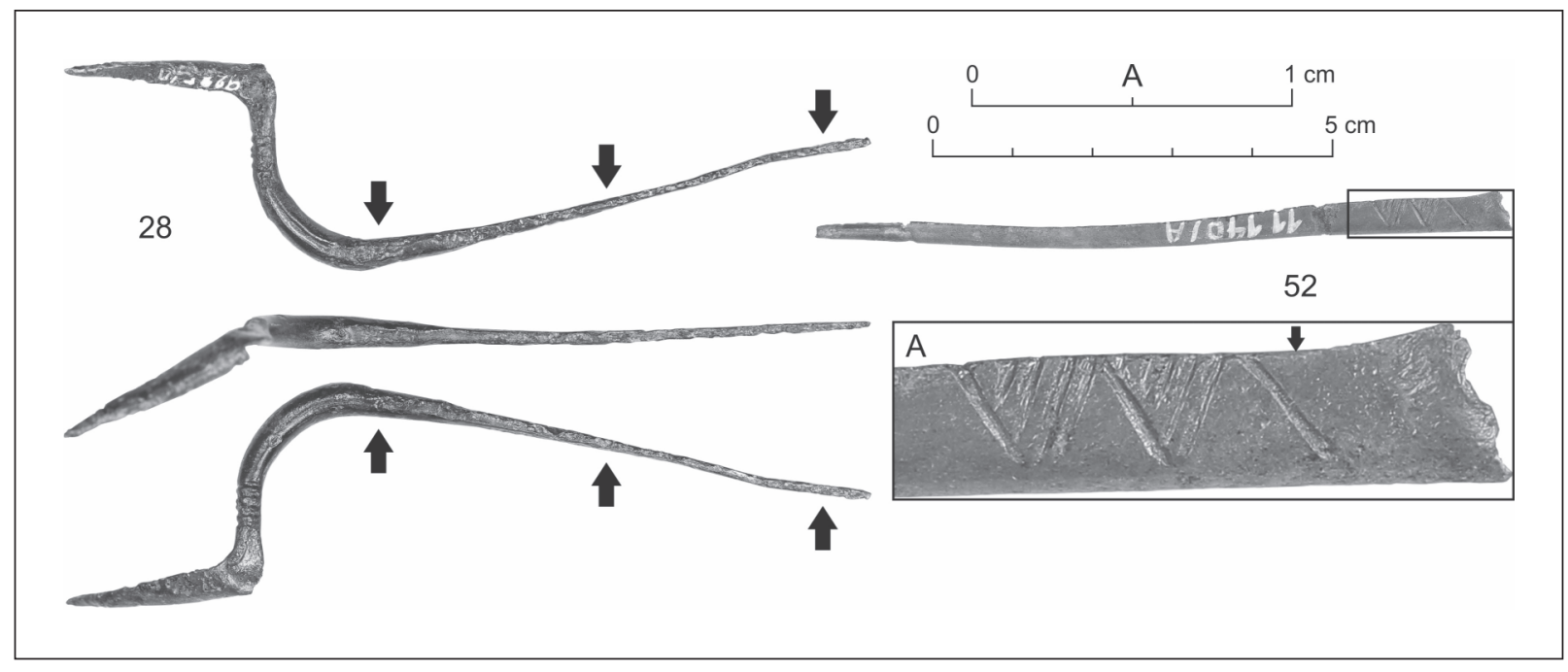

Obr. 2. Smolenice, poloha hradisko Molpír (okr. Trnava). Vybrané nálezy nedokončených výrobkov halštatských spôn z III. nádvoria hradiska. Čísla nálezov zodpovedajú číslovaniu v tabele 1. 28, 52 - zliatiny medi. Grafická mierka a detail v rámčeku zodpovedajú vyznačenej grafickej mierke. Fotografie a vizualizácia M. Felcan.

Typy jednotlivých spôn z Molpíra analyzované nedeštruktívnou metódou RFA sú: nezdobená lúčovitá spona s jednou slučkou, lúčovité spony zdobené priečnymi líniami, lúčovitá spona s organickou častou na drôtenom lučíku, lúčovitá spona s trojuholníkovým prierezom lučíku, lod’kovitá spona typu Šmarjeta, lod'kovitá spona so širokým lučíkom, lod'kovitá spona s postrannými výčnelkami na lučíku, nezdobená lod'kovitá spona, lod'kovitá spona zdobená mriežkovanými priečnymi pásikmi (nesprávne v literatúre označované ako ryté pásiky, na čo neskôr poukážeme), hadovitá spona, fragmenty vinutí, ihlíc a zachycovačov bližšie neurčitelných halštatských spôn.

\section{K TRASOLÓGII, KONŠTRUKCIÁM A TECHNOLÓGII VÝROBY VYBRANÝCH PREDMETOV}

Snaha získat kovy z rúd sa traduje od počiatku ludskej civilizácie. Medzi kovy, ktoré sa ako prvé začali používat patrili zlato a med', ked’že boli dostupné v rýdzej forme. Popri samostatných kovoch sa začali používat zliatiny, medzi ktorými popredné miesto zaujímajú zliatiny medi. Tie sa získavali legovaním, a to pridávaním legujúcich prísad do vsádzky alebo do tekutého kovu, aby sa dosiahlo požadované chemické zloženie. Keďže náleziská suroviny potrebnej na legovanie boli zväčša na vzájomne odlahlých miestach, tak výrobcovia boli odkázaní na rozsiahly transport týchto surovín a obchod.

Z typologického hladiska sú predmetom nášho trasologického a technologického výskumu lod'kovité spony typu Šmarjeta (obr. 1: 59, 61), lod'kovité spony zdobené mriežkovanými priečnymi pásikmi (obr. 1: 25; 3: 45), lúčovité spony zdobené priečnymi líniami (obr. 1: 2; 2: 28) a fragment zachycovača bližšie neurčenej halštatskej spony (obr. 2: 52).

Pri sledovaní výrobných postupov je nutné odrazit sa od základnej, makroskopicky pozorovatelnej trasológie daných predmetov. Viacero spôn z Molpíra poskytuje množstvo zaujímavých stôp, ktoré boli rozpoznané. Jedným z najdôležitejších trasologických pozorovaní je zistenie výzdobnej techniky sekania alebo zásekov do suroviny medenej zliatiny. Táto technológia býva často nesprávne interpretovaná ako technológia rytia, alebo technológia rytej výzdoby (napr. Novotná 2001). Výzdobnú technológiu sekania možno pozorovat takmer na každej jednej sledovanej spone z Molpíra. Bola uplatňovaná na sponách typu Šmarjeta v zmysle šikmého alebo priečneho sekania stredovej a dvoch postranných líšt lučíku spony (obr. 1: 59, 61), ktoré vystúpili zbrúsením ich medzipriestoru. Výzdobnú techniku možno sledovat aj v jednoduchšej forme priečnych zásekov na lučíku a zachycovači lúčovitých spôn (obr. 2: 28), ktoré boli vyrábané už aj zo železa (obr. 1: 2). Najväčšie uplatnenie dosiahla táto výzdobná technika pri lod'kovitých sponách zdobených mriežkovanými priečnymi pásmi na lučíku. Ide o skupinu spôn, ktorá je typologicky na Molpíre najväčšmi zastúpená po sponách typu Šmarjeta. V ukončenom prípade výzdoby sekaním boli mrežované priečne pásy na lučíku striedané s brúsenými hladkými pásmi (obr. 1: 25). Existuje 
však aj spona tohto typu, ktorá má hned' niekol'ko známok nedokončeného výrobku (obr. 3). Prvým z nich sú prečnievajúce záseky do medzipásov, ktorým chýba patričný výbrus, ako ho možno pozorovat' na väčšine spôn tohto typu. Na tejto spone je dokonca vidiet postup sekania. Najprv boli do vrchnej strany lučíku vysekané priečne línie smerom na os spony (obr. 3: A, značené šípkami) až potom šikmé línie. Druhým podstatným signifikantom nedokončenia spony sú výrazné stopy po kovaní a tvarovaní lučíku, ale aj zachycovača (obr. 3: C, B, značené šípkami). Každá z lod'kovitých spôn si nepochybne prešla týmto procesom kovania a tvarovania po odliatí. Na väčšine z nich však boli tieto stopy vo finálnom procese vybrúsené a zahladené. Na príklade spony 45 možno dobre doložit jej výrobný proces. Mriežkované záseky na vrchnej strane lučíku museli vzniknút bezprostredne pred kovaním a tvarovaním lučíka spony do tzv. „lod"ky“. Následne bol lučík aj zachycovač tvarovaný kovaním a údermi smerom do spodnej a vnútornej strany lučíka i zachycovača, pričom ich vonkajšia čast̉ musela byt fixovaná v tvarovo kompatibilnej forme. Podstatným zistením pri sekaní a kovaní medenej zliatiny je, že daný predmet musel byt' nahrievaný do určitej teploty, aby bol daný úkon realizovatelný. Túto tézu bude potrebné $\mathrm{v}$ budúcnosti overit experimentom. $\mathrm{V}$ každom prípade nie každé nahriatie predmetu a jeho následné kovanie boli dokonalé, o čom svedčia aj vzniknuté praskliny (obr. 3: C, vertikálne šípky). Metódu nahrievania a následného sekania možno pozorovat aj v nedokončenom vzore na zachycovači bližšie neurčenej halštatskej spony (obr. 2: 52A, pozícia šípky). Tento zachycovač spony bol tiež s najväčšou pravdepodobnostou súčastou neukončenej remeselnej činnosti na Molpíre.

S kovaním a tvarovaním odliatkov halštatských spôn súvisí aj nedokončený výrobok lúčovitej spony s priečnymi sekanými líniami na lučíku (obr. 2: 28). Smer šípok na obrázku poukazuje na stopy vykúvania budúceho vinutia a ihly tejto spony. Posledný úkon vinutia však nebol opät ukončený, a preto možno s určitostou tvrdit', že daná spona bola na hradisku Molpír vyrábaná.

Dôležitým technologickým zlomom $\mathrm{v}$ kovovýrobe zliatin medi doby halštatskej je nitovanie. Nitovanie je zastúpené v mnohých prípadoch spôn z Molpíra a je problematické rozoznat jeho intencionalitu pri výrobe novej spony a pri opravovaní zlomených častí jednotlivých spôn. Považujeme však za nesprávnu typologickú klasifikáciu niektorých typov spôn na základe prítomnosti nitu na jedno a viacdielne (napr. Novotná 2001). Dôvodom je používanie nitovania nezávisle na type danej spony (obr. 1;3). Najčastejším miestom spájania dvoch častí spony nitom je prechod medzi lučíkom a začiatkom vinutia spony (obr. 1: 2D, 25B, 59A; 3: 45A, väčšia šípka). Toto miesto možno považovat' za najviac namáhané používaním spony, čo nabáda k interpretácii nitovania ako opravnej techniky. V ojedinelých prípadoch bolo nitovanie použité aj na iných častiach spôn, ako napríklad prechod lučíka a zachycovača spony typu Šmarjeta (obr. 1: 61C). V prospech interpretácie techniky nitovania ako opravnej hovoria aj stopy po viacnásobnom opravovaní nitom (minimálne dvojnásobnom) d’alšej spony typu Šmarjeta na prechode lučíka a vinutia (obr. 1: 59A). Nitovanie sa používalo aj v prípade ojedinelejších železných spôn (obr. 1: 2D). Obidve časti spôn vyrobené zo zliatin medi museli byt๋ najprv nahrievané na určitú teplotu a následne jemne roztepané. Potom musel byt do nich prerazený otvor pre nit a spojené boli samotným nitom, ktorý bol na obidvoch stranách roztepaný. V prípade lod'kovitej spony $25 \mathrm{~s}$ mriežkovanými priečnymi pásikmi možno na základe RFA meraní luč́́ka, zachycovača, ihly a nitu (tabela 1: 25) jednoznačne doložit rozdielnost̉ chemického zloženia. Lučík, ktorý tvorí so zachycovačom jeden kompaktný kus vykazujú podobné hodnoty hlavných aj stopových prvkov. Ihla a nit sa v tomto prvkovom zložení od nich aj navzájom pomerne výrazne odlišujú. Znamená to, že pokial bola spona takto zámerne vyrobená, jej výrobca intencionálne použil na rôzne časti spony inú surovinu kvôli namáhaniu jednotlivých častí používaním. Pokial' bola spona opravovaná nitovaním, nebola na jej opravu použitá pôvodná ihla s vinutím. Odlišný prípad reprezentuje lod'kovitá spona typu Šmarjeta, spojená nitom v mieste prechodu lučíka a zachycovača (obr. 1: 61). Merania RFA tu preukázali takmer zhodné chemické zloženie hlavných aj stopových prvkov lučíka aj zachycovača (tabela 1: 61). Znamená to, že táto spona bola zlomená v danom mieste a znovu spojená nitom jej dvoch pôvodných kusov lučíka a zachycovača, a teda bola opravovaná.

Prezentovaný rebrovaný náramok (obr. 4: 85) je najvýraznejší zástupca tohto typu náramkov z Molpíra, ktorý má najvýznamnejšie pozorovatelné stopy po neukončenom spracovaní výrobku. Na mapovom podklade georeliéfu tretieho nádvoria hradiska (obr. 5) sú vynesené všetky náramky s rebrovaním, pri ktorých boli pozorované stopy po neukončenom spracovaní. Ako bolo vyššie zmienené, uvedený náramok bol už spolu s ostatnými predmetmi v tejto štúdii publikovaný (obr. 4: 85D; Dušek/ Dušek 1995, tab. 86: 4). Viac ako jeho typologická vypovedacia hodnota je v tomto prípade zaujímavá jeho trasologicko-technologická vypovedacia hodnota, ktorá na uvedenej kresbe nie je vôbec dokumentovaná. Náramok má niekol'ko stôp nedokončeného výrobku. Asi najvýraznejšie sa prejavuje výrastok, ako pozostatok po nalievacom kanáliku odlievacej formy náramku (obr. 4: 85A). Zároveň sú na ňom po- 
zorovatel'né záseky a následné ulomenie za účelom jeho odstránenia po odliatí a vychladnutí odliatku zliatiny medi. Ďalšie výrazné stopy nedokončenej práce má samotné telo náramku. Ide o menšie výliatky nachádzajúce sa predovšetkým medzi rebrami náramku (obr. 4: 85B, C). Vznikli procesom odlievania $\mathrm{v}$ mieste napojenia a drobných medzier jednotlivých dielov odlievacej formy. Všetky dokumentované stopy jednoznačne vypovedajú o nedokončenom a nedobrúsenom výrobku rebrovaného náramku, ktorý bol aj spolu s d’alšími s najväčšou pravdepodobnostou odliaty priamo na hradisku Molpír.

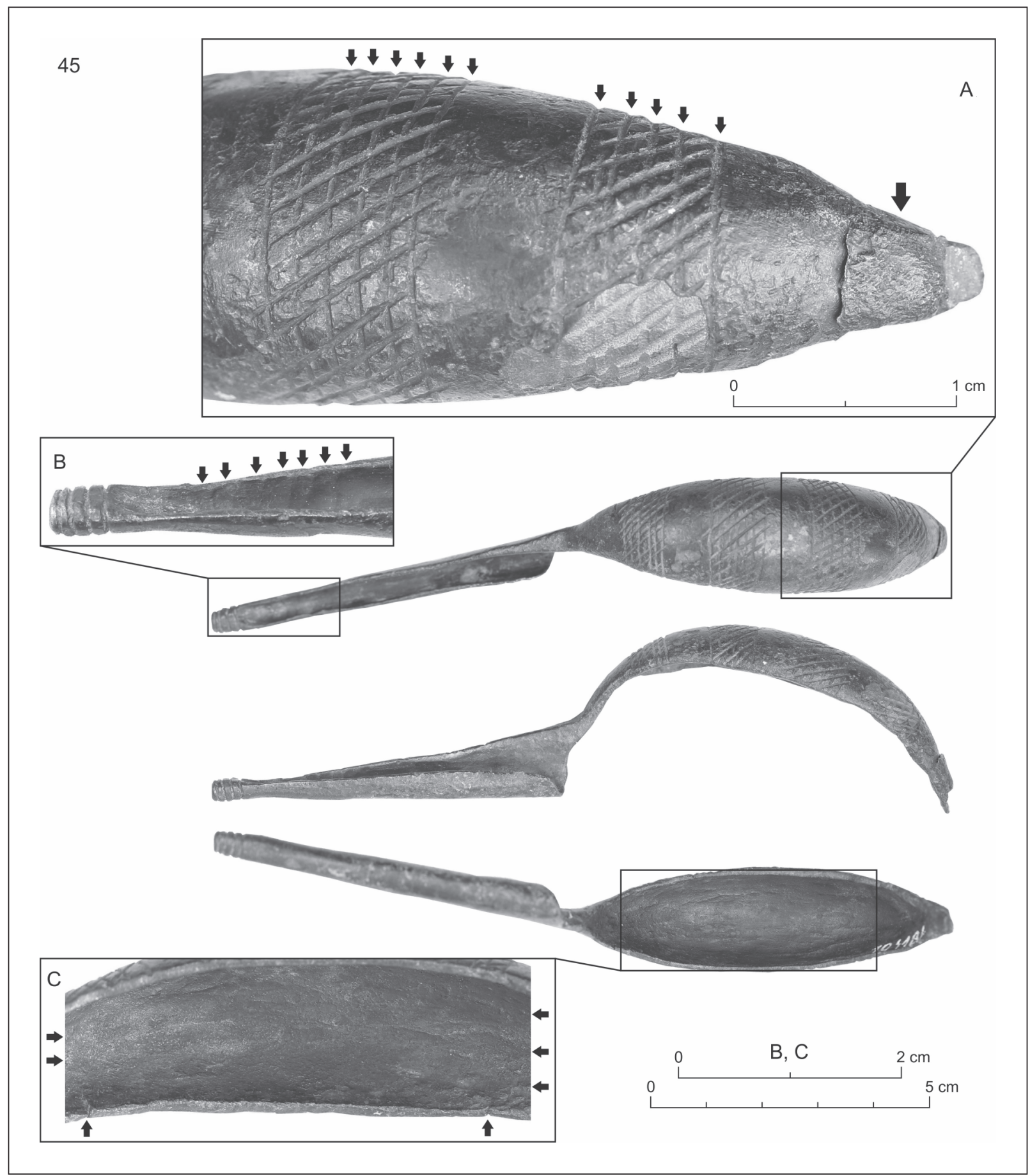

Obr. 3. Smolenice, poloha hradisko Molpír (okr. Trnava). Nález nedokončeného výrobku halštatskej spony z III. nádvoria hradiska. Číslo nálezu zodpovedá číslovaniu v tabele 1. 45 - zliatina medi. Grafická mierka a detail v rámčeku zodpovedajú vyznačenej grafickej mierke. Fotografie a vizualizácia M. Felcan. 
RFA analýza chemického zloženia spôn a náramkov predstavuje v tejto štúdii len predbežnú ukážku niektorých možností interpretácie technologických postupov. Preukázala sa ako nápomocná metóda pri ich objasňovaní, no v budúcnosti ju bude potrebné zdokonalovat kvantifikovaním meraní na daný predmet a testovaním inými metódami (NAA). Vzhl’adom na vysokú variabilitu prvkového zloženia meraných predmetov (tabela 1) je nutné prehodnotit aj terminologickú otázku samotného bronzu. Vzhladom na vysoké obsahy hlavných prvkov ako cín (Sn), alebo olovo (Pb), ktoré v niektorých meraniach predmetov dosiahli vyššie hodnoty ako samotná med' $(\mathrm{Cu})$ by bolo vhodnejšie namiesto termínu bronz používat termín „zliatina medi“ alebo termín „medené zliatiny“.

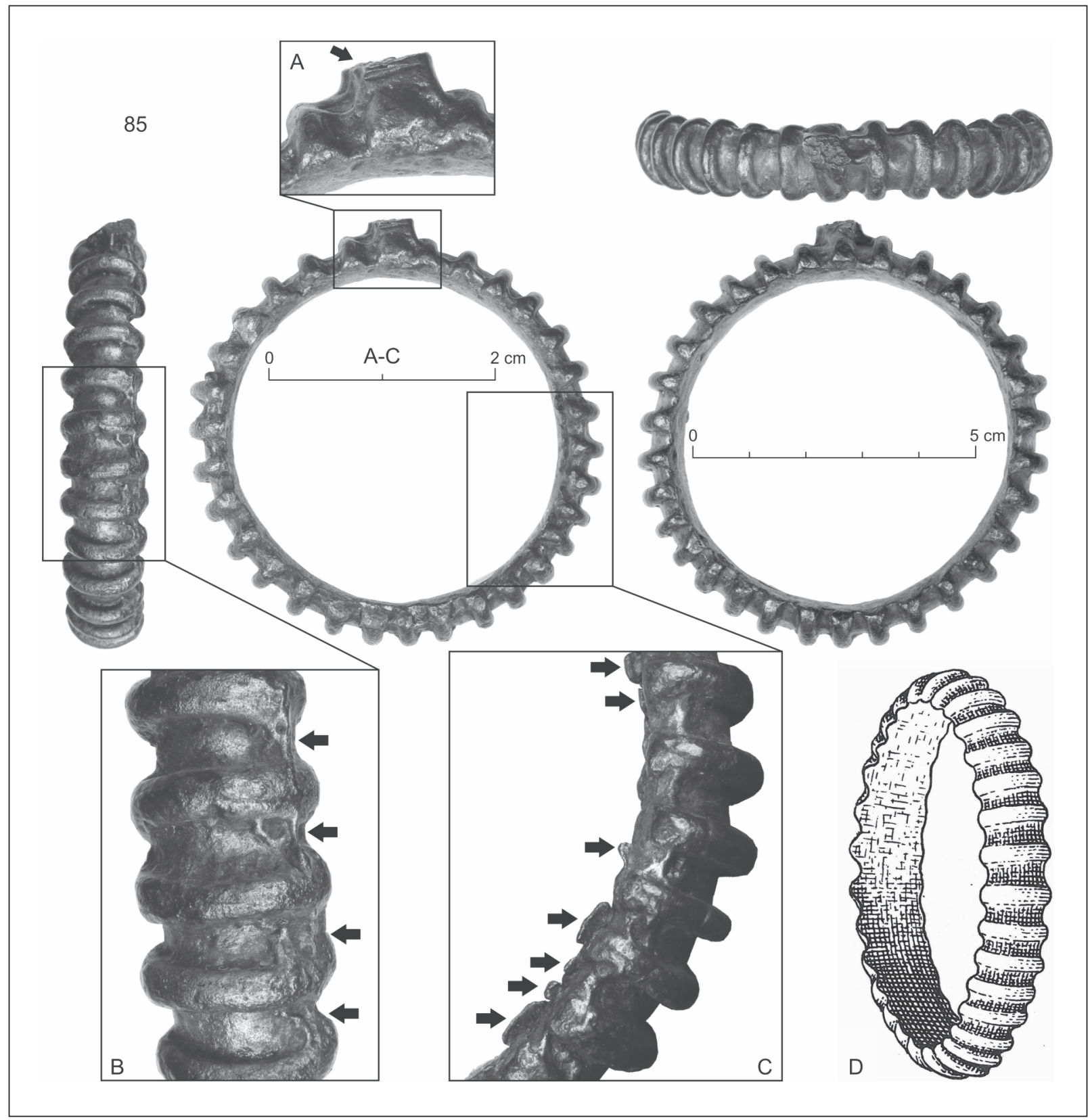

Obr. 4. Smolenice, poloha hradisko Molpír (okr. Trnava). Nález odliatku nedokončeného halštatského náramku s rebrovaním z III. nádvoria hradiska. Číslo nálezu zodpovedá číslovaniu v tabele 1. 85 - zliatina medi. Grafická mierka a detaily v rámčekoch zodpovedajú označenej grafickej mierke; D - podla Dušek/Dušek 1995, tab. 86: 4; bez mierky. Fotografie a vizualizácia M. Felcan. 


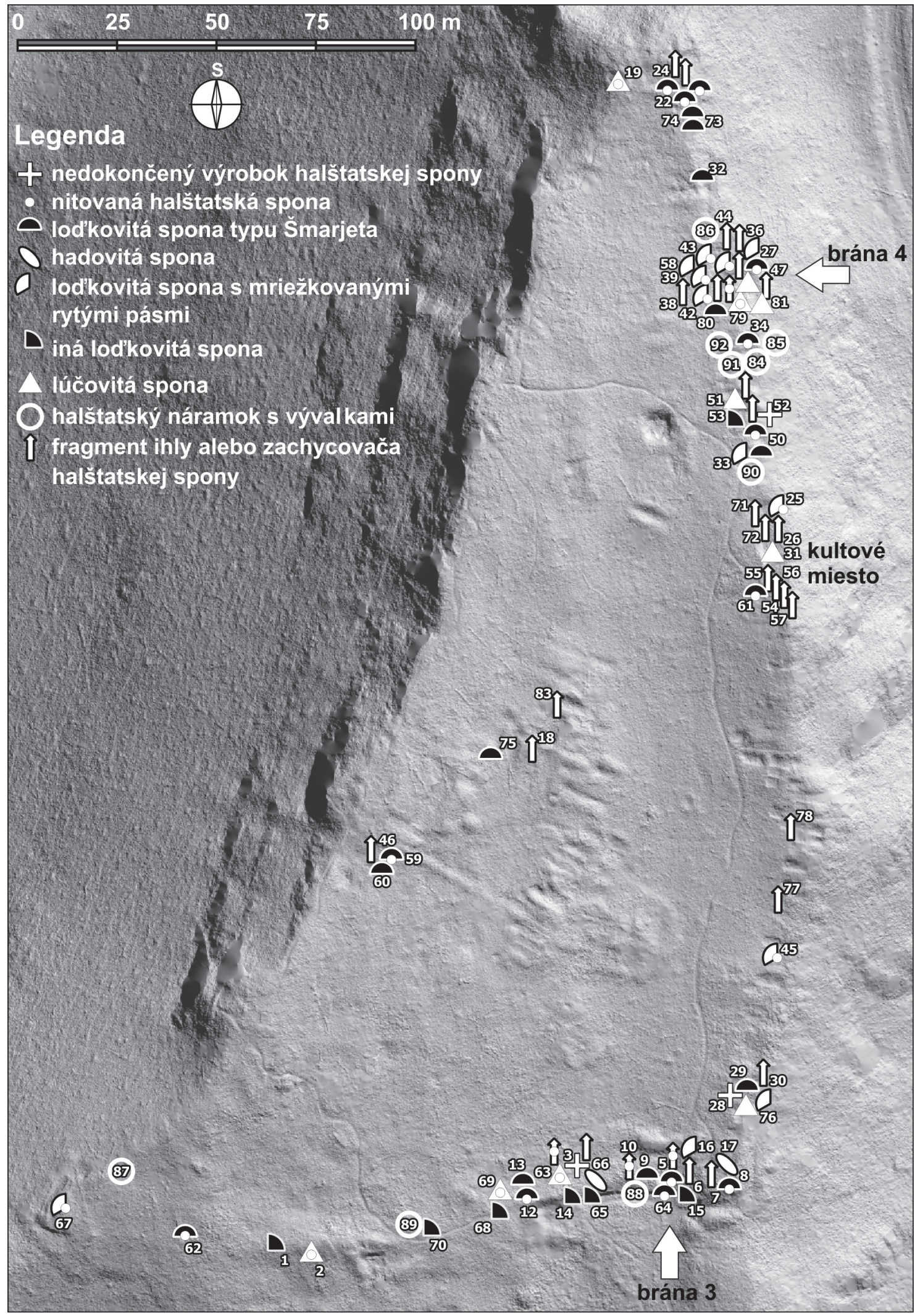

Obr. 5. Smolenice, poloha hradisko Molpír (okr. Trnava). Distribúcia analyzovaných spôn a náramkov v rámci III. nádvoria hradiska na podklade tieňovaného modelu reliéfu. Čísla nálezov zodpovedajú číslovaniu v tabele 1. Vizualizácia M. Felcan. 


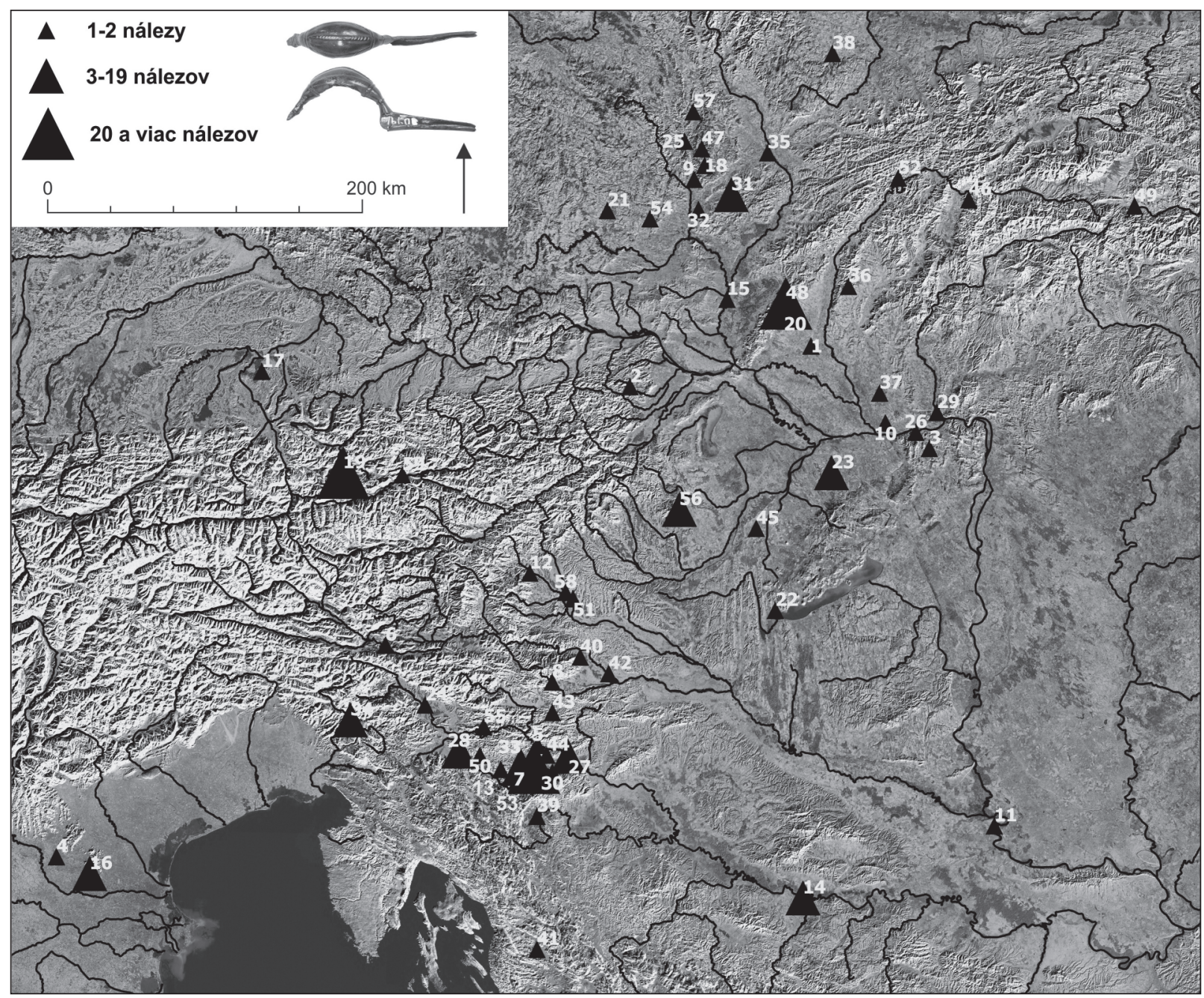

Obr. 6. Rozšírenie lod'kovitých spôn typu Šmarjeta vo východoalpskom regióne. 1 - Abrahám; 2 - Alland; 3 - Bajna; 4 - Baldaria; 5 - Boštanj-Mali Lukovec; 6 - Breg-Frög; 7 - Brezje pri Trebelnem; 8 - Brinjeva gora; 9 - Brno-Obřany; 10 Chotín; 11 - Dalj; 12 - Dietenberg; 13 - Dobrnič; 14 - Donja Dolina; 15 - Drösing; 16 - Este-Villa Benvenuti; 17 - Gilgenberg; 18 - Habrůvka-Býčí skála; 19 - Hallstatt; 20 - Horné Orešany-Slepý vrch; 21 - Jaroměřice nad Rokytnou-Hradisko; 22 - Keszthely; 23 - Kisravazd-Ravazd; 24 - Kranj; 25 - Krhov-Malý Chlum; 26 - Lábatlan; 27 - Libna; 28 - Magdalenska gora; 29 - Malá nad Hronom; 30 - Malence; 31 - Marefy-Člupy; 32 - Měnín; 33 - Mokronog; 34 - Most na Soči-Sveta Lucija II; 35 - Nezamyslice; 36 - Nitrianska Blatnica-Marhát; 37 - Nové Zámky-Ragoňa; 38 - Opava-Kylešovice; 39 - Podzemelj; 40 - Poštela pri Razvanju; 41 - Prozor; 42 - Ptuj-Rabeljčja vas; 43 - Rifnik; 44 - Rovišče pri Studencu; 45 - Sághegy; 46 - Sklabinský Podzámok-Katova skala; 47 - Sloup-Kůlna; 48 - Smolenice-Molpír; 49 - Spišské Tomášovce-Čertova diera; 50 - Stična; 51 - St. Georgen bei Stiefling; 52 - Stupné-Žeravica; 53 - Šmarjeta; 54 - Těšetice-Sutny; 55 - Vače; 56 - Velem-Szentvid; 57 - Velké Opatovice-Hradisko; 58 - Wildon; 59 - Wörschach-Wolkenstein. Vizualizácia M. Felcan (doplnené podla Glunz 1997, mapa 24; Parzinger 1995, obr. 7; Teržan 1990, mapa 16).

\section{ZÁVER}

Za doklady remeselnej metalurgickej činnosti na Molpíre v dobe halštatskej možno považovat' nálezy nedokončených náramkov či početné nálezy spôn. Všetky analyzované kovové predmety prezentované v tejto štúdii pochádzajú z III. nádvoria hradiska Molpír. Rekonštrukcia technológií výroby kovových predmetov medených zliatin, ako aj železných predmetov a organizácie šperkárskeho, kovolejárskeho a kovotepeckého remesla v staršej dobe železnej na tomto hradisku nebola dosial' systematicky sledovaná a vyhodnotená. Postupné spracovávanie rozsiahleho nálezového materiálu prináša konkrétne výsledky aj ku konštrukciám a technológiám výroby niektorých typov kovových predmetov. V rámci nálezov z výskumov Molpíra sa vyskytuje množstvo železných a iných neinterpretovaných predmetov, ktoré 
môžu byt๋ nástrojmi používanými na opracovanie sledovaných spôn. Zdá sa, že nielen pradenie a tkanie, teda výroba textilu, patrili k hospodárskym a ekonomickým pilierom komunít žijúcich na Molpíre v staršej dobe železnej.

Na väššine skúmaných náramkov z III. nádvoria Molpíra sú pozorovatel'né stopy neukončeného odlievacieho procesu a samotné predmety nesú známky nedokončených výrobkov. Na sponách možno pozorovat stopy brúsenia, kovania a nitovania alebo rôzne formy dekorácie vytvárané prevažne technikou nahrievania kovu a sekania (zásekov), ktorá sa zvykne často nesprávne interpretovat’ ako technika rytia, rytej výzdoby. Rovnako bývajú typologicky nesprávne delené niektoré spony typu Šmarjeta, ale aj iné podla prítomnosti nitu a spájania nitovaním na jednodielne a viacdielne (Novotná 2001). Preukázali sme, že poškodenie spony a následná oprava roztepaním a spojením nitom dvoch zlomených častí spony nie je hlavným markantom pre typológiu predmetov, ale len prakticky ekonomickou záležitostou. K výskumu techniky nitovania nám výrazne pomohla aj RFA analýza chemického zloženia medených zliatin. Štúdium pracovných stôp a technologických postupov stažuje množstvo faktorov ako rôzne deformácie predmetov spôsobené žiarom, mechanické deformácie, korózia s patinou, ale aj moderné konzervačné zásahy.

V rámci III. nádvoria hradiska Molpír sa nám podarilo lokalizovat niekolko zvýšených koncentrácií spôn a náramkov prezentovaných v tejto štúdií (obr. 5). Obzvlášt dôležitá je lokalizácia nedokončených a opravovaných výrobkov spôn spolu s nedokončenými výrobkami rebrovaných náramkov. Koncentrácie týchto predmetov možno pozorovat predovšetkým v priestoroch preskúmaných brán 3 a 4 III. nádvoria hradiska a takzvaného kultového miesta.

Hradisko Molpír (obr. 6: 48) predstavuje v rámci celého východohalštatského kultúrneho okruhu na východ od Álp jednu z troch lokalít, na ktorej bolo nájdených 20 a viac kusov spôn typu Šmarjeta. Nálezová situácia je o to vzácnejšia, že nálezy spôn z Molpíra predstavujú sídliskové nálezy, zatial čo zvyšné dve lokality, Hallstatt a Smarjeta (obr. 6: 19, 53) reprezentujú pohrebiskové nálezy spôn. Molpír teda predstavuje sídliskovú výšinnú opevnenú polohu s najvyšším počtom nálezov lod’kovitých spôn typu Šmarjeta, ale aj lod’kovitých spôn zdobených mriežkovanými priečnymi pásikmi. V rámci aktualizácie distribučnej mapy spôn typu Śmarjeta pozorujeme výrazný nárast počtu týchto spínadiel v oblasti západných Karpát a Moravy. Velmi ojedinelý je nedávny nález strieborného vyhotovenia spony typu Šmarjeta zo severozápadného Slovenska z polohy Stupné-Žeravica. Podla RFA analýzy autora spona obsahuje až 88,25 \% striebra (Ag) a len 11,75 \% medi (Cu; Fröhlich 2016, 15).

Pri pozorovaní stôp opracovania sa podarilo preukázat produkciu a opravovanie niektorých konkrétnych typov spôn a náramkov. Je to aj vd’aka tomu, že Molpír je sídlisková lokalita, zatial čo v prípade predmetov z pohrebísk by nebolo možné nájsț tol'ko nedokonalostí spracovania daných artefaktov. Tento enormný výskyt spôn zároveň nastoluje konkrétnu otázku, a to odkial' sa vlastne spony rozšírili, je to vôbec možné zistit?? Zdá sa, že pohyb ludí, transport tovarov, "know how" a obchod fungoval viacerými smermi, nielen $\mathrm{v}$ rámci obchodných trás $\mathrm{z}$ juhovýchodu smerom na severovýchod (napr. Parzinger/ Nekvasil/Barth 1995, obr. 11).

\section{LITERATÚRA}

Barta a i. 2017

Bayley 1988

Becka i. 1985

Belanová 2002
Bayley 1989

P. Barta/P. Kmetová/S. Stegmann-Rajtár/K.-U. Heussner/A. Šivo: Archived radiocarbon and dendrochronological samples from Smolenice-Molpír: a contributionon site use in the Early Iron Age and the formation of the archaeological record. In: E. Miroššayová/Ch. Pare/S. Stegmann-Rajtár (ed.): Das nördliche Karpatenbecken in der Hallstattzeit: Wirtschaft, Handel und Kommunikation in früheisenzeitlichen Gesellschaften zwischen Ostalpen und Westpannonien. Archaeolingua 38. Budapest 2017, 527-546.

J. Bayley: Non-ferrous metalworking: continuity and change. Science and Archaeology. British Archaeological Reports 196, 1988, 193-208.

J. Bayley: Analysis and examination of roman brooches from Tiddington, Warwickshire. Ancient Monuments Laboratory Report 85/89, 1989, 1-11.

F. Beck/M. Menu/T. Berthoud/L. P. Hurtel: Metallurgie des bronzes. In: J. Hoirs (ed.): Recherches Gallo-Romaines I. Paris 1985, 70-139.

T. Belanová: Doklad produkcie textilu vo východoalpskej halštatskej oblasti. Možnosti využitia exaktných analytických metód v archeológii (Filozofická fakulta UK). Diplomová práca. Bratislava 2002. Nepublikované.

Bertemes 1989

F. Bertemes: Das frühbronzezeitliche Gräberfeld von Gemeinlebarn. Bonn 1989. 
Charles 1973

Condamin/Boucher 1973

Craddock 1978

Craddock a i. 2010

Dušek/Dušek 1984

Dušek/Dušek 1995

Felcan/Pašteka/Stegmann-Rajtár, v tlači

Frána a i. 1995

Frána a i. 1997

Fröhlich 2016

Glunz 1997

Hellmuth 2006

Janšák 1929

Janšák 1930

Könyöki 1905

Ludwig/Stegmann-Rajtár/Tirpák 2010

Müller 2012

Müller 2017

Northover 2009

Novotná 2001

Ottaway 1982

Parzinger 1995

Parzinger/Nekvasil/Barth 1995

Parzinger/Stegmann-Rajtár 1988

Patek 1993
J. A. Charles: Heterogenity in Metals. Archaeometry 15, 1973, 104-114.

J. Condamin/S. Boucher: Recherches techniques sur des bronzes de Gaule Romaine. Galia 31, 1973, 157-183.

P. T. Craddock: The composition of the copper alloys used by the Greek, Etruscan and Roman Civilizations 3. The origins and early use of brass. Journal of Archaeological Science 5, 1978, 1-16.

P. Craddock/M. Cowell/D. Hook/M. Hughes/S. La Niece/N. Meeks: Change and stasis: the technology of Dark Age metalwork from the Carpathian Basin. British Museum Technical research bulletin 4, 2010, 55-65.

M. Dušek/S. Dušek: Smolenice-Molpír. Befestigter Fürstensitz der Hallstattzeit I. Materialia Archaeologica Slovaca VI. Nitra 1984.

M. Dušek/S. Dušek: Smolenice-Molpír. Befestigter Fürstensitz der Hallstattzeit II. Materialia Archaeologica Slovaca XIII. Nitra 1995.

M. Felcan/R. Pašteka/S. Stegmann-Rajtár: Research of Early Iron Age Hillfort Smolenice-Molpír in Western Carpathians, new results and perspectives. In: Bringing down the Iron Curtain: paradigmatic changes in research on the Bronze Age in the Central and Eastern Europe. $18^{\text {th }}$ meeting of the EAA. V tlači.

J. Frána/L. Jiráň/A. Maštalka/V. Moucha: Artifacts of Copper and Copper Alloys in prehistoric Bohemia from the viewpoint of Analyses of Element Composition. Památky archeologické. Supplementum 3. Praha 1995.

J. Frána/L. Jiráň/V. Moucha/P. Sankot: Artifacts of Copper and Copper Alloys in prehistoric Bohemia from the viewpoint of Analyses of Element Composition II. Památky archeologické. Supplementum 8. Praha 1997.

J. Fröhlich: Poklad keltských šperkov a mincí z kultového miesta na kopci Žeravica pri obci Stupné na Slovensku. Folia Numismatica 30, 2016, 3-25.

B. Glunz: Studien zu den Fibeln aus dem Gräberfeld von Hallstatt, Oberösterreich. Linz 1997.

A. Hellmuth: Untersuchungen zu den sogennanten skythischen Pfeilspitzen aus der befestigten Höhensiedlung von Smolenice-Molpír. Universitätsforschungen zur prähistorischen Archäologie 128. Bonn 2006.

S. Janšák: Slovenské hradiská z doby halštatskej. Sborník Muzeálnej slovenskej spoločnosti 23, 1929, 1-23.

S. Janšák: Praveké osídlenie Slovenska. Sborník Muzeálnej slovenskej spoločnosti 24, 1930, 1-67.

J. Könyöki: A közepköri várak. Budapest 1905.

K. Ludwig/S. Stegmann-Rajtár/J. Tirpák: Geofyzikálna prospekcia a obnovený systematický výskum na akropole v Smoleniciach-Molpíre. Študijné zvesti Aú SAV 47, 2010, 41-52.

S. Müller: Smolenice-Molpír, Sered' und Ratkovce. Studien zu Siedlungen der frühen Eisenzeit in der Südwestslowakei. Universitätsforschungen zur prähistorischen Archäologie 220. Bonn 2012.

S. Müller: Die hallstattzeitliche Höhensiedlung Smolenice-Molpír. Überlegungen zur funktionalen und sozialen Struktur. In: E. Miroššayová/Ch. Pare/S. Stegmann-Rajtár (ed.): Das nördliche Karpatenbecken in der Hallstattzeit: Wirtschaft, Handel und Kommunikation in früheisenzeitlichen Gesellschaften zwischen Ostalpen und Westpannonien. Archaeolingua 38. Budapest 2017, 547-569.

P. Northover: Analysis and metallography of copper alloy metalwork. In: A. Lippert/P. Stadler (ed.): Das spätbronze- und früheisenzeitliche Gräberfeld von Bischofshofen-Pestfriedhof, Teil 1. Bonn 2009, 351-384.

M. Novotná: Die Fibeln in der Slowakei. Prähistorische Bronzefunde XIV/11. Stuttgart 2001.

B. S. Ottaway: Earliest Copper artifacts of the Northalpine region. Their analysis and evaluation. Schriften des Seminars für Urgeschichte der Universität Bern 7. Bern 1982.

H. Parzinger: II. Archäologische Beiträge. In: H. Parzinger/J. Nekvasil/F. E. Barth (ed.): Die Býči skála-Höhle. Mainz am Rhein 1995, 16-127.

H. Parzinger/J. Nekvasil/F. E. Barth: Die Býči skála-Höhle. Ein hallstattzeitlicher Höhlenopferplatz in Mähren. Römisch-Germanische Forschungen 54. Frankfurt am Main 1995.

H. Parzinger/S. Stegmann-Rajtár: Smolenice-Molpír und der Beginn skythischer Sachkultur in der Südwestslowakei. Prähistorische Zeitschrift 63, 1988, 162178.

E. Patek: Westungarn in der Hallstattzeit. Quellen und Forschungen prähistorischer und provinzialrömischer Archäologie 7. Weinheim 1993. 
Riederer/Briese 1974

Sándorfi 1890

Sándorfi 1896

Stegmann-Rajtár 1992

Stegmann-Rajtár 1998

Stegmann-Rajtár 2001

Stegmann-Rajtár 2002a

Stegmann-Rajtár $2002 b$

Stegmann-Rajtár 2005

Stegmann-Rajtár 2009

Stegmann-Rajtár 2017

Teržan 1990

Tirpák/Tirpáková/Zábojník 2017

Wobrauschek/Haider/Streli 1987

Wouters a i. 1991
J. Riederer/E. Briese: Metallanalysen römischer Gebrauchsgegenstände. Jahrbuch des Römisch-Germanischen Zentral Museums Mainz 19, 1974, 83-88.

N. Sándorfi: A Szomoláni (Pozsonymegye) östelepröl. Archaeologiai Értesitő 9, 1890, 420-423.

N. Sándorfi: A Szomoláni ásatások. Archaeologiai Értesitó 16, 1896, 109 -118.

S. Stegmann-Rajtár: Spätbronze- und früheisenzeitliche Fundgruppen des mittleren Donaugebietes. Bericht der Römisch-Germanischen Kommission 73, 1992, 29-179.

S. Stegmann-Rajtár: Spinnen und Weben in Smolenice-Molpír - Ein Beitrag zum wirtschatlichen und religiös-kultischem Leben der Bewohner des Hallstattzeitlichen Fürstensitzes. Slovenská archeológia 46, 1998, 263-287.

S. Stegmann-Rajtár: Kulturelle Beziehungen des hallstattzeitlichen Burgwalls Smolenice-Molpír. Pravěk. Nová řada 10, 2001, 457-471.

S. Stegmann-Rajtár: Früheisenzeitliche Fernverbindungen entlang dem Ostalpenrand. In: A. Lang/V. Salač (Hrsg.): Fernkontakte in der Eisenzeit, Konferenz Liblice 2000. Praha 2002, 254-269.

S. Stegmann-Rajtár: Keramika ako kritérium regionálneho členenia kultúrnej oblasti. Tvar a výzdoba hrobovej keramiky v severovýchodohalštatskom kultúrnom okruhu. Študijné zvesti AÚ SAV 35, 2002, 193-202.

S. Stegmann-Rajtár: Smolenice-Molpír. In: H. Beck/D. Geuenich/H.Steuer (ed.): Reallexikon der Germanischen Altertumskunde 29, Berlin - New York 2005, 146-156. S. Stegmann-Rajtár: Žiarové pohrebisko východohalštatskej a vekerzugskej kultúry v Nových Zámkoch. Príspevok k pohrebiskám doby halštatskej vo východoalpsko-zadunajskej oblasti. Slovenská archeológia 57, 2009, 57-116.

S. Stegmann-Rajtár: Zur Abfolge der Osthallstatt- und der Vekerzug-Kultur: Ein Überblick zur zum Forschungsstand der Hallstattzeit in der Südwestslowakei. In: E. Miroššayová/Ch. Pare/S. Stegmann-Rajtár (ed.): Das nördliche Karpatenbekken in der Hallstattzeit: Wirtschaft, Handel und Kommunikation in früheisenzeitlichen Gesellschaften zwischen Ostalpen und Westpannonien. Archaeolingua 38. Budapest 2017, 383-402.

B. Teržan: Starejša železna doba na Slovenskem Štajerskem/The early Iron Age in Slovenian Styria. Katalogi in monografije 25. Ljubljana 1990.

J. Tirpák/A. Tirpáková/J. Zábojník: Use of Discriminant Analysis of Data from the Fluorescence Spectometry Analysis of Archaeological Metal Artefacts. Statistika 97, 2017, 33-44.

P. Wobrauschek/W. Haider/C. Streli.: Röntgenfluoreszenzanalyse von Bronzefunden aus der Awarenzeit. In: F. Daim (ed.): Das awarische Gräberfeld von Leobersdorf, Niederösterreich. Band 2. Studien zur Archäologie der Awaren 3. Wien 1987, 45-55.

H. J. Wouters/L. A. Butaye/F. C. Adams/P. E. Van Espen: Spectroscopic Investigation of Tin-Rich Surfaces on Bronze Age Copper Alloys. In: E. Pernicka/G. A. Wagner (ed.): Archaeometry '90. Basel - Boston - Berlin 1991.

\title{
New data on constructions and technologies of Hallstatt period jewellery production from Smolenice-Molpír
}

\author{
Michal Felcan - Susanne Stegmann-Rajtár - Ján Tirpák
}

Summary

Finds of unfinished bracelets or numerous finds of fibulae can be considered evidence of metallurgical craft in Molpír during the Hallstatt period. All analyzed metal objects presented in this study come from Courtyard III of the Molpír hillfort. Reconstruction of technologies of production of metal objects using copper alloys and production of iron objects as well as organization of jewellery making, metal casting and smithery in the Early Iron Age at this hillfort has not been systematically monitored or assessed. Gradual processing of the rich material finds brings specific 
results related also to the constructions and technologies of production of some types of metal objects. Finds from investigations in Molpír include numerous iron and other uninterpreted artifacts which could be tools used to process fibulae. It seems that not only spinning and weaving, i. e. textile production, were economic pillars of communities living in Molpír in the Early Iron Age.

Most studied bracelets from Courtyard III in Molpír bear visible traces of imperfect casting process and the artifacts themselves have features of unfinished products. We can see traces of abrasion, smithing and riveting or various forms of decoration made mostly by the method of heating and cutting (cuts) of metal which is often wrongly interpreted as the technique of engraving or engraved decoration. Some fibulae of the Šmarjeta type as well as other types are also often incorrectly divided into one-piece fibulae or fibulae consisting of several pieces depending on presence of a rivet and connection by rivetting (Novotná 2001). We have shown that damage to a fibuala and subsequent repair by smithing and connecting the two broken parts of the fibula with rivets is not the main feature for typology of artifacts; it is just a practical-economical matter. XRF analysis of chemical composition of copper alloys was a great help for investigation of the technique of riveting. Studying the traces of work and technological processes is complicated by numerous factors, e. g. various deformations of items caused by heat, mechanical deformations, corrosion with patina and modern conservation techniques.

Within Courtyard III of the Molpír hillfort, we were able to localize several higher concentrations of fibulae and bracelets presented in this study (Fig. 5). Localization of unfinished and repaired products of fibulae together with unfinished ribbed bracelets is particularly important. Concentrations of these artifacts can be observed mainly in the areas of the studied gates 3 and 4 at Courtyard III of the hillfort and the so-called cult place.

In the whole East Hallstatt cultural sphere east of the Alps, the hillfort of Molpír (Fig. 6: 48) represents one of the three sites where 20 or more Šmarjeta type fibulae were found. The find situation is even more unique since the finds of fibulae from Molpír are settlement finds while the other two sites - Hallstatt and Šmarjeta (Fig. 6: 19, 53) represent finds of fibulae from burial grounds. Thus, Molpír is a fortified hillfort site with the highest number of finds of navicella fibulae of Šmarjeta type and boat-shaped fibulae decorated with transverse bands forming a grid. A significant increase in the number of such fasteners in the territory of the Western Carpathians and Moravia is visible on the updated distribution map of Šmarjeta type fibulae. A recent find of a silver Šmarjeta type fibula from norhtwestern Slovakia, Stupné-Žeravica site, is very unique. According to XRF analysis by the author, the fibula contains as much as $88.25 \%$ of silver (Ag) and only $11.75 \%$ of copper (Cu; Fröhlich 2016, 15).

Production and repairing of some specific types of fibulae and bracelets was documented when traces of processing were observed. It was also possible thanks to the fact that Molpír is a settlement site, while the artifacts from burial grounds did not show so many imperfections of processing. This enormous occurrence of fibulae also raises the following quenstion: Where did the fibulae come from and is it possible to find out? It seems that moving of people, transportation of goods, the know-how and trade worked in several directions, not only within trade routes from southeast towards northeast (Parzinger/Nekvasil/Barth 1995, fig. 11).

Fig. 1. Smolenice, hillfort Molpír (dist. Trnava). Selected finds of Early Iron Age fibulae from the Courtyard III of the hillfort. Numbers of finds correspond with the numbering used in Table 1. 2 - iron; 25, 59, 61 - copper alloys. Graphic scale as well as details in frames correspond with the depicted graphic scale. Photographies and visualization M. Felcan.

Fig. 2. Smolenice, hillfort Molpír (dist. Trnava). Selected finds of unfinished products of Early Iron Age fibulae from the Courtyard III of the hillfort. Numbers of finds correspond with the numbering in Table 1. 28, 52 - copper alloys. Graphic scale and detail in frame correspond with the depicted graphic scale. Photographies and visualization M. Felcan.

Fig. 3. Smolenice, hillfort Molpír (dist. Trnava). Find of unfinished product of Early Iron Age fibulae from the Courtyard III of the hillfort. Number of find correspond with the numbering in Table 1. 45 - copper alloy. Graphic scale and detail in frame correspond with the depicted graphic scale. Photographies and visualization M. Felcan.

Fig. 4. Smolenice, hillfort Molpír (dist. Trnava). Find of cast of unfinished Early Iron Age bracelet with ribbing from the Courtyard III of the hillfort. Number of find corresponds with the numbering in Table 1. 85 - copper alloy. Graphic scale and details in frames correspond with the depicted graphic scale; D - after Dušek/Dušek 1995, Tab. 86: 4; without scale. Photographies and visualization M. Felcan.

Fig. 5. Smolenice, hillfort Molpír (dist. Trnava). Distribution of the analyzed fibulas and bracelets within the Courtyard III of the hillfort on shaded relief model. Numbers of finds correspond with the numbering in Table 1. Visualization M. Felcan.

Fig. 6. Distribution of boat shaped Šmarjeta fibula in Eastern Alpine region. 1 - Abrahám; 2 - Alland; 3 - Bajna; 4 Baldaria; 5 - Boštanj-Mali Lukovec; 6 - Breg-Frög; 7 - Brezje pri Trebelnem; 8 - Brinjeva gora; 9 - Brno-Obřany; 10 - Chotín; 11 - Dalj; 12 - Dietenberg; 13 - Dobrnič; 14 - Donja Dolina; 15 - Drösing; 16 - Este-Villa Benvenuti; 17 - Gilgenberg; 18 - Habrůvka-Býčí skála; 19 - Hallstatt; 20 - Horné Orešany-Slepý vrch; 21 - Jaroměřice nad Rokytnou-Hradisko; 22 - Keszthely; 23 - Kisravazd-Ravazd; 24 - Kranj; 25 - Krhov-Malý Chlum; 26 - Lábatlan; 27 - Libna; 28 - Magdalenska gora; 29 - Malá nad Hronom; 30 - Malence; 31 - Marefy-Člupy; 32 - Měnín; 33 - Mokronog; 34 - Most na Soči-Sveta Lucija II; 35 - Nezamyslice; 36 - Nitrianska Blatnica-Marhát; 37 - Nové Zámky-Ragoňa; 38 - Opava-Kylešovice; 39 - Podzemelj; 40 - Poštela pri Razvanju; 41 - Prozor; 42 - Ptuj-Rabeljčja vas; 43 - Rifnik; 44 - Rovišče pri Studencu; 45 - Sághegy; 46 - Sklabinský Podzámok-Katova skala; 47 - Sloup-Kůlna; 48 - Smolenice- 
Molpír; 49 - Spišské Tomášovce-Čertova diera; 50 - Stična; 51 - St. Georgen bei Stiefling; 52 - Stupné-Žeravica; 53 - Šmarjeta; 54 - Těšetice-Sutny; 55 - Vače; 56 - Velem-Szentvid; 57 - Velké Opatovice-Hradisko; 58 - Wildon; 59 Wörschach-Wolkenstein. Visualization M. Felcan (complemented with new finds after Glunz 1997, map 24; Parzinger 1995, Fig. 7; Teržan 1990, map 16).

Table 1. Smolenice, hillfort Molpír (dist. Trnava). The results of XRF analysis of fibulaes and bracelets from the Early Iron Age. Measured by J. Tirpák.

Mgr. Michal Felcan, PhD.

Pamiatkový úrad Slovenskej republiky

Cesta na Červený most 6

SK - 81406 Bratislava

michal.felcan@pamiatky.gov.sk

doc. RNDr. Ján Tirpák, CSc.

Gemologický ústav

Fakulta prírodných vied

Univerzita Konštantína Filozofa

Nábrežie mládeže 91

SK - 94974 Nitra

jtirpak@ukf.sk
PhDr. Susanne Stegmann-Rajtár, CSc.

Archeologický ústav SAV

Akademická 2

SK - 94921 Nitra

zuzana.rajtarova@savba.sk 
